cell metabolism, chemotherapy, dermatology, genetics, gynæcology, hæmatology, medicine, pathology, physiology, psychiatry, public health, sociology and virology (Annual Report of the Medical Research Council of Ireland, 1960. Pp. i+64. Dublin: Medical Research Council of Ireland, 1961).

\section{The Chest and Heart Association}

In a pithy annual report entitled Outlook for Health, the Chest and Heart Association reports that lung cancer deaths are increasing steadily by a thousand a year in England and Wales - in 1960 there were $21,992,18,867$ of them being men (Pp. 6. London: The Chest and Heart Association, 1961). To combat bronchitis, which afflicts one person in every twenty, the Association recommends a holiday away from the polluted air of the industrial centres in which so many patients live and work. Tuberculosis still causes more than 3,000 deaths a year in Great Britain, and there are more than 300,000 people on the chest clinic registers. Each year more than 20,000 new cases of tuberculosis are found, and this is no longer predominantly a disease of the young. More than half the new cases were men over the age of forty-five. The Association, with the co-operation of the Federal Government of Nigeria, is sponsoring a Conference to be held at University College, Ibadan, during March 26-31. The programme will include lectures and panel discussions on tuberculosis, leprosy, community infection, drug treatment, surveys and village hygiene.

\section{Systems of National Accounts in Africa}

The Working Party on Economic Studies of the Commission for Technical Co-operation in Africa South of the Sahara recommended in February 1958 preparation of a factual report on methods of national accounting used in Africa South of the Sahara, and taking into account the systems of national accounts prepared by international organizations. This recommendation was adopted by the Commission at its Session at Brussels in May 1958 when Miss P. Ady and M. Michel Courcier were asked to prepare the report, with Mr. M. Gilbert, of the Organization for European Economic Co-operation, as consultant. A draft of the report, which is in four chapters, was discussed at a further Working Party in December 1959 , when publication was recommended, subject to certain changes. The bulk of the report consists of the fourth chapter setting forth the definitions and methods in use in African countries (Pp. 232. Paris: Organization for European Economic Co-operation; London: H.M.S.O., 1961. 8.50 NF.; 12s. 6d.; 2 dollars).

\section{National Museum of Canada, 1910-60}

Dr. Loris S. Russele has done a service to the museum world by compiling a history of the National Museum of Canada for the period 1910-60, partly from his own experience and partly from those who participated in the earlier years (The National Museum of Canada, 1910 to 1960. Pp. v+37. Ottawa: Queen's Printer, 1961. 50 cents). The history of the building, collections and administration is clearly traced and an interesting record, with photographs, is given of those curators who were responsible for the work. Although research by the staff and others is encouraged and is expanding, even greater opportunity is given to the public to view the Museum's treasures and sample its accumulated knowledge.

\section{The Museums Journal}

No. 3, Volume 61 , of the new format of The Museums Journal is a delightful blend of euratorial and technical papers. The former includes one on William Scott by Mr. John Russell, and public collections and social justice by Mr. Richard Wollheim. In the latter category Mr. Crawford Ross writes on the problems incurred in labelling biological material, Dr. Michael Eager discusses light typing on dark backgrounds, and Mr. David Northrop details the difficult tasks encountered in cleaning and repairing the Golden Rose. Various papers given at the annual conference in 1961 are summarized.

\section{Educational Aids in Metallurgy, Physics, Engineer- ing and Chemistry}

Two new publications featuring educational services made available free of charge to science masters in grammar, public and technical schools, and lecturers in universities and technical colleges are now obtainable from the International Nickel Company (Mond), Ltd. Publication 2415 describes educational aids which are particularly relevant to the General Certificate of Education Ordinary and Advanced Level examinations. This booklet lists specimens, photographs and samples, wall charts, films $(16 \mathrm{~mm}$. sound/colour) and publications dealing with a wide variety of metallurgical and associated subjects. Publication 2414 describes educational aids which are more specially suited to the requirements of lecturers in metallurgy, physics, engineering and chemistry. Copies of the publications are available from the International Nickel Company (Mond), Ltd., Thames House, Millbank, London, S.W.1.

\section{Current Scientific Publications by South African Universities}

THE register of current scientific research at South African universities is based on replies to questionnaires, and the entries are printed as received, except for occasional corrections and condensations ( $\mathrm{Pp}$. vi+112. Pretoria: South African Council for Scientific and Industrial Research, 1961. $R$. 1.50). English translations are provided where the returns were received in Afrikaans, and the alphabetical arrangement is also based on English. Entries are arranged alphabetically under each university, the main grouping being by broad subjects. There are 768 entries and subject and author indexes in English.

\section{al-Zahräwi's Tenth-Century Surgical Treatise}

Probably the earliest independent work in Arabic Spain to embrace the whole of the medical knowledge of that time is the encyclopædic al-Tasrif, written in the late tenth century by Abū al-Qäsim al-Zahrāwi, also known as Abulcasis. Consisting of thirty treatises, it is the only known work of al-Zahrãwi, and brought him high prestige in the Western World. His last treatise, on surgery, is the subject of a paper by Sami Hamarneh in a contribution to the Museum of History and Technology of the Smithsonian Institution: United States National Museum (Paper 22: Drawings and Pharmacy in al-Zahräwi's 10thCentury Surgical Treatise. Pp. 81-94. Washington, D.C.: Government Printing Office, 1961. 20 cents). With its many drawings of surgical instruments, intended for the instruction of apprentices, its descriptions of formulæ and medicinal preparations, and its lucid observations on surgical procedures, this treatise is perhaps the oldest of its kind. There is available a translation of the text and reproductions 